\title{
Pneumocystis jirovecii-related spontaneous pneumothorax, pneumomediastinum and subcutaneous emphysema in a liver transplant recipient: a case report
}

Wong Hoi She ${ }^{1}$, Kenneth S. H. Chok ${ }^{1,2^{*}}$ D, Iris W. S. Li ${ }^{3}$, Ka Wing Ma ${ }^{1}$, Sui Ling Sinn ${ }^{1}$, Wing Chiu Dai ${ }^{1}$, James Y. Y. Fung ${ }^{2,4}$ and Chung Mau Lo ${ }^{1,2}$

\begin{abstract}
Background: Pneumocystis pneumonia (PCP) is a common opportunistic infection caused by Pneumocystis jirovecii. Its incidence at 2 years or more after liver transplant $(\mathrm{LT})$ is $<0.1 \%$. PCP-related spontaneous pneumothorax and/or pneumomediastinum is rare in patients without the human immunodeficiency virus, with an incidence of 0.4-4\%.

Case presentation: A 65-year-old woman who had split-graft deceased-donor LT for primary biliary cirrhosis developed fever, dyspnea and dry coughing at 25 months after transplant. Her immunosuppressants included tacrolimus, mycophenolate mofetil, and prednisolone. PCP infection was confirmed by molecular detection of Pneumocystis jirovecii,in bronchoalveolar lavage. On day-10 trimethoprim-sulphamethoxazole, her chest X-ray showed subcutaneous emphysema bilaterally, right pneumothorax and pneumomediastinum. Computed tomography of the thorax confirmed the presence of right pneumothorax, pneumomediastinum and subcutaneous emphysema. She was managed with 7-day right-sided chest drain and a 21-day course of trimethoprim-sulphamethoxazole before discharge.

Conclusion: Longer period of PCP prophylaxis should be considered in patients who have a higher risk compared to general LT patients. High index of clinical suspicion, prompt diagnosis and treatment with ongoing patient reassessment to detect and exclude rare, potentially fatal but treatable complications are essential, especially when clinical deterioration has developed.
\end{abstract}

Keywords: Pneumocystis jirovecii, Pneumocystis pneumonia, Post-liver transplant, Primary biliary cirrhosis

\section{Background}

Pneumocystis pneumonia (PCP) is a common opportunistic infection caused by Pneumocystis jirovecii affecting immunosuppressed patients with significant morbidity and mortality [1-3]. The incidence of PCP at 2 years or more after liver transplant (LT) is < $0.1 \%$ [2-4]. PCP-related spontaneous pneumothorax with or without pneumomediastinum is relatively uncommon in patients without the human immunodeficiency virus (HIV), with an incidence

\footnotetext{
* Correspondence: kennethchok@gmail.com

1 Department of Surgery, The University of Hong Kong, 102 Pok Fu Lam Road, Hong Kong, China

${ }^{2}$ State Key Laboratory for Liver Research, The University of Hong Kong, 102

Pok Fu Lam Road, Hong Kong, China

Full list of author information is available at the end of the article
}

of $0.4-4 \%$ [5]. PCP co-infection with other viruses is occasionally seen and cytomegalovirus (CMV) is more common than with respiratory syncytial virus (RSV) and other viruses $[2,6,7]$.

\section{Case presentation}

A 65-year-old non-smoking and non-drinking woman had split-graft deceased-donor LT for end-stage primary biliary cirrhosis (PBC) (Tables 1 \& 2 ). No pre-LT induction immunosuppressant was given. Her post-LT immunosuppressants included oral tacrolimus (1 mg twice daily) and mycophenolate mofetil (180 mg twice daily). She also had prednisolone (10 $\mathrm{mg}$ twice daily) immediately after LT and gradually tapered to

(c) The Author(s). 2019 Open Access This article is distributed under the terms of the Creative Commons Attribution 4.0 International License (http://creativecommons.org/licenses/by/4.0/), which permits unrestricted use, distribution, and 
Table 1 Results of investigation performed for primary biliary cirrhosis and liver transplant workup

\begin{tabular}{ll}
\hline Test performed & Results (Reference range) \\
\hline Pre-transplant & \\
Hepatitis serology & \\
HBsAg & Negative \\
Anti-HBs & $<10 \mathrm{mlU} / \mathrm{mL}$ \\
Anti-HBC (total) & Negative \\
Anti-HAV (total) & Positive \\
Anti-HAV IgM & Negative \\
Autoimmune markers & \\
C3 & 135 (76-150) mg/dL \\
C4 & 26 (9-35) mg/dL \\
ANA titre & Could not be interpreted due \\
Anti-ds DNA & to cytoplasmic staining \\
Anti-smooth muscle Ab & $7(0-35)$ IU/ml \\
Anti-mitochrondrial Ab & Negative \\
Immunoglobulin (lg) pattern & Positive, M2 pattern \\
IgG & \\
IgA & 3540 (819-1725) mg/dL \\
IgM & 407 (70-386) mg/dL \\
Lung function test & 474 (55-307) mg/dL \\
Forced vital capacity (FVC) & $2.23 \mathrm{~L}, 96 \%$ \\
the 1 sec/FVC (FEV1/FVC) & $70 \%$ predicted \\
& impending cirrhosis \\
&
\end{tabular}

This admission

Blood culture

Nasopharyngeal aspirate

\section{Sputum culture}

Mid-stream/Catheterized

urine culture

Serum Cryptococcal antigen

Plasma CMV pp65 Antigen

Bronchoalveolar lavage fluid

$$
\begin{aligned}
& \text { - Gram stain } \\
& \text { - Bacterial culture } \\
& \text { - Acid fast bacilli (AFB) } \\
& \text { smear and culture } \\
& \text { - Fungal smear / culture }
\end{aligned}
$$

- TB-PCR

\section{No growth}

Polymerase chain reaction (PCR) positive for Respiratory syncytial virus (RSV) and Enterovirus(EV)/ Rhinovirus (RV)

Negative for Influenza A virus, Influenza B virus, Parainfluenza virus, Adenovirus, human metapneumovirus

Candida albicans

No growth

Negative

Negative

\section{No organism seen}

Candida species

Negative and no growth of AFB

Smear negative / Candida albicans

Negative
Table 1 Results of investigation performed for primary biliary cirrhosis and liver transplant workup (Continued)

\begin{tabular}{ll}
\hline Test performed & Results (Reference range) \\
\hline $\begin{array}{l}\text { - Pneumocystis jirovecii } \\
\text { qualitative PCR }\end{array}$ & Positive \\
- CMV qualitative PCR & Positive \\
- Respiratory viruses antigen & Positive for RSV \\
detection by immunofluorescence & \\
- Respiratory viruses & Positive for RSV \\
qualitative PCR & Negative for EV/RV, Influenza \\
& A virus, Influenza B virus, \\
& Parainfluenza virus, adenovirus, \\
& human metapneumovirus \\
Liver biopsy (28 months & Non-specific change \\
post-transplant) & \\
\hline Ab ant
\end{tabular}

$A b$ antibody, ANA anti-nuclear antibody, Anti-Hbc antibody to hepatitis B core antigen, $C M V$ cytomegalovirus, ds double-stranded, HAV hepatitis A virus, $H B s A g$ hepatitis B surface antigen, IgM immunoglobulin $M, N A$ not available, $T B$ tuberculosis

$5 \mathrm{mg}$ daily. Prophylactic medication included fluconazole (200 mg daily), trimethoprim-sulfamethoxazole (TMP-SMX) (480 mg daily) and acyclovir (400 mg tds) were also given for 3 months. She developed biliary anastomotic stricture and bile leakage, which improved with repeated endoscopic retrograde cholangiopancreatography with balloon dilatation without stenting. The last endoscopic retrograde cholangiopancreatography was performed at 22 months after LT. At 25 months after LT, she was admitted because of a 2-day history of fever, dyspnea and dry coughing. At admission, her blood pressure was $132 / 80 \mathrm{mmHg}$, pulse 106 beat per minute, and SpO2 88\% at ambient air. SpO2 improved to $95 \%$ with supplemental oxygen ( $2 \mathrm{~L} / \mathrm{min}$ ) via nasal cannula, but rapidly deteriorated requiring $100 \%$ oxygen via re-breathing mask to maintain SpO2 $\geq 92 \%$. Chest X-ray (Fig. 1a) and other investigations were performed (Tables 1 and 2). Pneumocystis jirovecii, CMV and RSV were detected in bronchoalveolar lavage by respective accredited in-house polymerase chain reaction. Her condition improved with intravenous TMP-SMX (trimethoprim component at $15 \mathrm{mg} / \mathrm{kg} / \mathrm{d}$ divided in every $8 \mathrm{~h}$ ), a tapering dose of corticosteroid for PCP and intravenous ganciclovir $(5 \mathrm{mg} / \mathrm{kg}$ every $12 \mathrm{~h}$ as induction, followed by $5 \mathrm{mg} / \mathrm{kg}$ every $24 \mathrm{~h}$ as maintenance) for CMV. Her immunosuppressants were reduced and tapered during the PCP treatment. On day-10 TMP-SMX, her chest X-ray showed subcutaneous emphysema bilaterally and right pneumothorax suspected of pneumomediastinum (Fig. 1b). Computed tomography of the thorax confirmed the presence of right pneumothorax, pneumomediastinum and subcutaneous emphysema (Fig. 2). She was managed with 7-day chest drain in 
Table 2 Profiles of laboratory investigations

\begin{tabular}{|c|c|c|c|c|c|c|c|c|}
\hline & Pre-transplant & $\begin{array}{l}\text { Day of } \\
\text { transplantation }\end{array}$ & $\begin{array}{l}24 \text { months } \\
\text { post-transplant }\end{array}$ & $\begin{array}{l}\text { Day of } \\
\text { hospital } \\
\text { admission }\end{array}$ & $\begin{array}{l}\text { Day of } \\
\text { pneumothorax } \\
\text { confirmed }\end{array}$ & $\begin{array}{l}\text { Day of } \\
\text { discharge } \\
\text { from hospital }\end{array}$ & $\begin{array}{l}30 \text { months } \\
\text { post-transplant }\end{array}$ & $\begin{array}{l}\text { Reference } \\
\text { range }\end{array}$ \\
\hline \multicolumn{9}{|l|}{ Complete blood picture } \\
\hline $\begin{array}{l}\text { white blood cell } \\
\left(w c c, \times 10^{9} / \mathrm{L}\right)\end{array}$ & 3.15 & 6.82 & 8.97 & 11.92 & 22.61 & 6.91 & 4.53 & $3.89-9.93$ \\
\hline Neutrophil $\left(\times 10^{9} / L\right)$ & 2.30 & 2.93 & 8.40 & 10.51 & 19.76 & 4.69 & 3.17 & $2.01-7.42$ \\
\hline $\begin{array}{l}\text { Lymphocyte } \\
\left(\times 10^{9} / \mathrm{L}\right)\end{array}$ & 0.50 & 0.75 & 0.43 & 0.63 & 1.93 & 1.66 & 1.05 & $1.06-3.61$ \\
\hline Monocyte $\left(\times 10^{9} / L\right)$ & 0.16 & 0.22 & 0.14 & 0.69 & 0.83 & 0.21 & 0.26 & $0.18-0.65$ \\
\hline $\begin{array}{l}\text { Hemoglobin } \\
(\mathrm{Hb}, \mathrm{g} / \mathrm{dL})\end{array}$ & 10.1 & 9.8 & 10.6 & 11.6 & 10.1 & 9.3 & 11.3 & $11.5-14.8$ \\
\hline Platelet $\left(\mathrm{Plt}, \times 10^{9} / \mathrm{L}\right)$ & 116 & 121 & 114 & 265 & 352 & 209 & 126 & $154-371$ \\
\hline \multicolumn{9}{|l|}{ Clotting profile } \\
\hline PT (sec) & 13.6 & 34.8 & 13.2 & 13.1 & 13.3 & 12.5 & 12.9 & \\
\hline INR & 1.2 & 3.1 & 1.1 & 1.1 & 1.1 & 1.0 & 1.1 & \\
\hline APTT (sec) & 30.3 & $>110.0$ & 25.7 & 29.1 & 26.1 & 22.5 & 26.8 & \\
\hline \multicolumn{9}{|l|}{ Renal function test } \\
\hline $\begin{array}{l}\text { Sodium } \\
\text { ( } \mathrm{Na}, \mathrm{mmol} / \mathrm{L})\end{array}$ & 141 & 153 & 139 & 140 & 129 & 139 & 143 & $136-148$ \\
\hline $\begin{array}{l}\text { Potassium } \\
(\mathrm{K}, \mathrm{mmol} / \mathrm{L})\end{array}$ & 3.7 & 4.1 & 4.7 & 4.6 & 4.0 & 3.5 & 5.0 & $3.6-5.0$ \\
\hline Urea (mmol/L) & 6.1 & 9.4 & 13.4 & 12.7 & 14.6 & 1.7 & 15.0 & $2.9-8.0$ \\
\hline Creatinine (umol/L) & 62 & 63 & 94 & 158 & 96 & 56 & 80 & $49-82$ \\
\hline \multicolumn{9}{|l|}{ Liver function test } \\
\hline Total protein $(\mathrm{g} / \mathrm{L})$ & 80 & 27 & 66 & 71 & 57 & 62 & 86 & $67-87$ \\
\hline Albumin (Alb, g/L) & 29 & $<10$ & 40 & 43 & 30 & 32 & 44 & $39-50$ \\
\hline Globulin (Glo, g/L) & 51 & 19 & 26 & 28 & 27 & 30 & 42 & $26-40$ \\
\hline $\begin{array}{l}\text { Bilirubin, total } \\
(\mu \mathrm{mol} / \mathrm{L})\end{array}$ & 126 & 127 & 7 & 21 & 5 & 7 & 8 & $4-23$ \\
\hline $\begin{array}{l}\text { Alkaline phosphatase } \\
(A L P, U / L)\end{array}$ & 264 & 41 & 91 & 92 & 116 & 145 & 115 & $47-124$ \\
\hline $\begin{array}{l}\text { Alanine transaminase } \\
\text { (ALT, U/L) }\end{array}$ & 106 & 1025 & 57 & 30 & 38 & 52 & 63 & $7-36$ \\
\hline $\begin{array}{l}\text { Aspartate transaminase } \\
\text { (AST, U/L) }\end{array}$ & 147 & 2339 & 26 & 24 & 63 & 47 & 50 & $14-30$ \\
\hline $\begin{array}{l}\text { Gamma-glutamyl } \\
\text { transferase (GGT, U/L) }\end{array}$ & 100 & 42 & 68 & 45 & NA & NA & 101 & Up to 35 \\
\hline Arterial blood gas & NA & NA & NA & & NA & NA & NA & \\
\hline $\mathrm{FiO} 2$ & & & & $21 \%$ & & & & \\
\hline $\mathrm{pH}$ & & & & 7.43 & & & & $7.35-7.45$ \\
\hline $\mathrm{pCO}_{2}(\mathrm{kPa})$ & & & & 4.0 & & & & $4.7-6.0$ \\
\hline $\mathrm{pO}_{2}(\mathrm{kPa})$ & & & & 12.7 & & & & $10.6-14.0$ \\
\hline Bicarbonate $(\mathrm{mmol} / \mathrm{L})$ & & & & 19 & & & & $22-26$ \\
\hline Base excess $(\mathrm{mmol} / \mathrm{L})$ & & & & -4 & & & & $-4-+2$ \\
\hline
\end{tabular}

NA not available

situ with a standard Argyle-type chest tube of Fr-32 until her right lung re-expanded, in addition to 21-day TMP-SMX. She was not put on mechanical ventilation.
She survived and was discharged on day 31 after admission. Chest X-ray on discharge showed resolution of the pneumothorax (Fig. 3). 

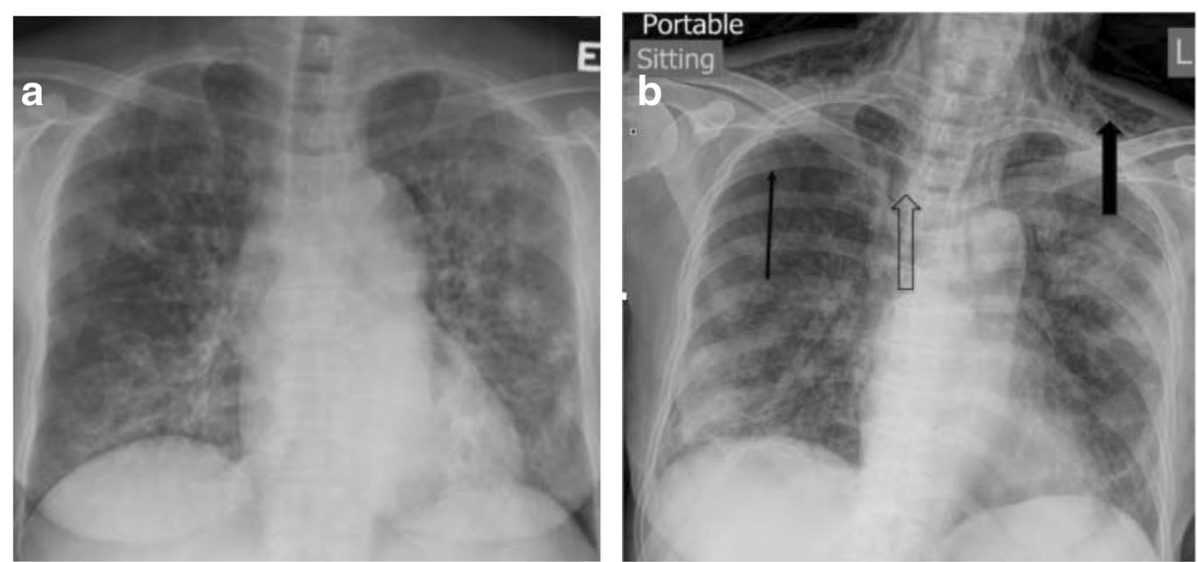

Fig. 1 a Chest X-ray on admission showing bilateral peri-hilar interstitial infiltrates. b Chest X-ray showing right pneumothorax (thin arrow), subcutaneous emphysema (solid arrow) and pneumomediastinum (hollow arrow)

\section{Discussion}

This case demonstrated PCP-related pneumothorax, pneumomediastinum and subcutaneous emphysema at 22 months after PCP prophylaxis in a recipient of LT for end-stage $\mathrm{PBC}$ at 25 months after transplant.

Pneumocystis jirovecii (previously Pneumocystis carinii) is considered a distinct species causing human PCP infection [8]. It is a yeast-like fungus of the genus Pneumocystis. It is an opportunistic agent affecting immune-compromised hosts. PCP is one of the conditions that define Acquired Immune Deficiency Syndrome (AIDS). It is more commonly seen in other immunosuppressed patients due to underlying diseases, immunosuppressants or chemotherapy [3].

The reported incidence of PCP in LT recipients without PCP prophylaxis is $3-11 \%$, which is the lowest among solid organ and bone marrow transplant recipients [2-4]. Most of the cases developed during the initial 6 to 9 months and $>70 \%$ developed within 12 months of

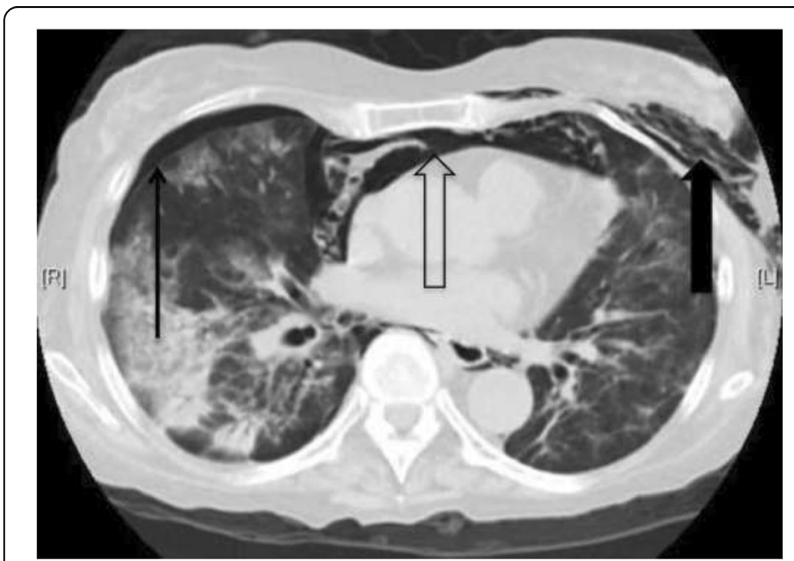

Fig. 2 Computed tomography of thorax showing right pneumothorax (thin arrow), pneumomediastinum (hollow arrow), and subcutaneous emphysema (solid arrow)
$\mathrm{LT}$, but the development could be as early as within 1 to 3 weeks of LT $[1,4]$. PCP prophylaxis is recommended for 6-12 months post-transplant [9]. In LT recipients with immediate post-LT 6-month TMP-SMX as PCP prophylaxis, the incidence of $\mathrm{PCP}$ was reported to be $0.3 \%$ at 6 months, $0.6 \%$ at $6-12$ months, $0.9 \%$ at 1 year, and $<0.1 \%$ at more than 1 year [1] , and the incidence at 12 months after LT was reported to be 0.24 per 1000 persons per transplant year [4].

The risk factors for PCP in our patient was prolonged use of prednisolone and simultaneous use of tacrolimus and mycophenolate mofetil, resulting in a reduction of CD4 T-cells (CD4) [10]. Although mycophenolate mofetil may have intrinsic activity against Pneumocystis

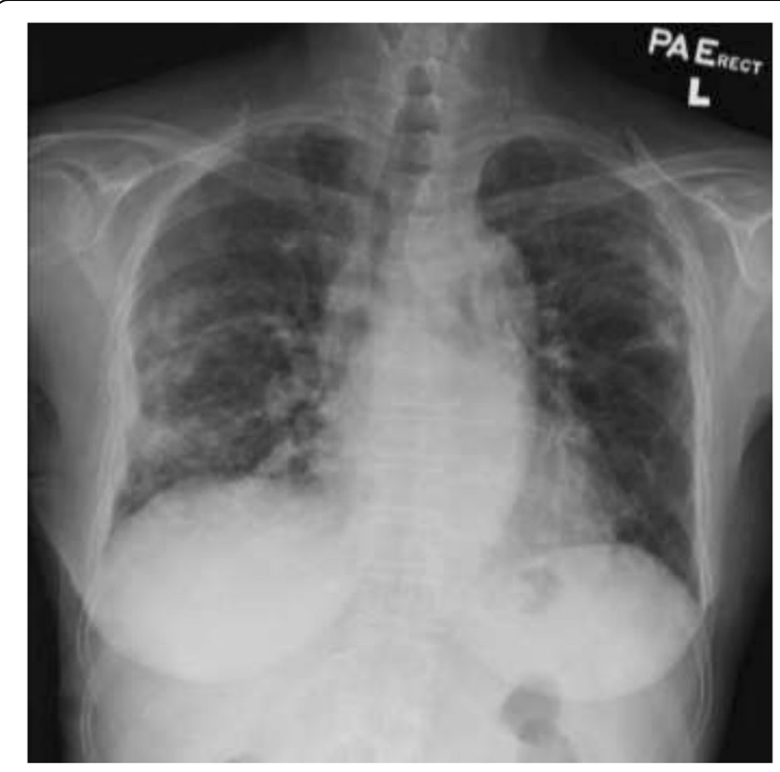

Fig. 3 Chest $X$-ray on discharge showing resolution of the pneumothorax 
jirovecii, tacrolimus has been found to boost the growth of Pneumocystis jirovecii in vitro $[11,12]$. In addition to lympholytic activity of steroid, the resultant depressed cell-mediated immunity rendered our patient susceptible to opportunistic infections [13]. In earlier reports, corticosteroid use and depressed cell-mediated immunity were significant risk factors for PCP in non-HIV patients, irrespective of the use of mechanical ventilation [14]. In non-HIV patients with PCP, $>80 \%$ had prednisolone use at $\geq 20 \mathrm{mg} /$ day for $\geq 1$ month, and $25 \%$ had corticosteroid as a monotherapy immunosuppressant. LT recipients without PCP prophylaxis developed PCP even just on prednisolone at $5 \mathrm{mg} /$ day to $20 \mathrm{mg} /$ day $[3,4,14]$. Our patient received oral prednisolone at $5 \mathrm{mg} /$ day for 25 months, lower than the median dose of 41.8 (22.3-61.5) $\mathrm{mg} /$ day but longer than the duration of corticosteroid use of 4.8 (1.8-10.1) months reported in a cohort of non-HIV patients with $\mathrm{PCP}$ who required mechanical ventilation, including $12.5 \%$ of LT recipients [6].

Moreover, the depressed cell-mediated immunity also resulted in latent CMV reactivation, which also acted as immunosuppressive agent suppressing T-helper and antigen-presenting cells' functions [13]. The clinical significance of compartmentalized CMV reactivation in bronchoalveolar lavage might be controversial but should not be overlooked, given our patient's clinical context. In non-HIV patients with PCP who required mechanical ventilation, 29 and $2.1 \%$ of the respiratory specimens were found to be PCP with CMV or RSV co-infection respectively [6]. A significantly higher rate of PCP with co-infection has been found in non-surviving non-HIV patients than those surviving [10]. Thirdly, our patient's $\mathrm{PBC}$ might be related to depressed cell-mediated immunity. $\mathrm{PBC}$ patients have a significantly lower level of circulating CD4 than healthy persons, irrespective of simultaneous alveolitis [15], and have detectable mitochondrial antigen-specific-CD4 in peripheral blood, liver-drainage lymph nodes and liver, which is not found in healthy or other liver-diseased persons [16]. Hence, PBC may be a systemic autoimmune disease affecting lungs and/or other organs, apart from its well-established tissue-specificity targeting intrahepatic biliary epithelial cells [17]. We did not check the CD4 level of our patient, as this is currently used only in the HIV patients. Our patient's pre-LT total lymphocyte count of 500 cells $/ \mu \mathrm{L}$ (Table 2) predicted a CD4 level of $<200$ cells/ $\mu \mathrm{L}$ [18]. Furthermore, she received steroid for $\mathrm{PBC}$-associated autoimmune disease and anti-rejection immunosuppressants, which rendered her susceptible to PCP. Unfortunately, she could not receive long-term PCP prophylaxis due to underlying renal impairment.

Her acute 2-day symptoms were concordant with the shorter symptom duration $(20 \%$ in $<3$ days, or $\sim 5$ to 6 days) in non-HIV patients with $\mathrm{PCP}$, as compared to sub-acute and longer symptom durations (25 to 28 days) observed in HIV patients with PCP [3, 13, 14]. She survived despite the high mortality of PCP: $>80 \%$ in adult LT recipients, and $30-40 \%$ in non-HIV patients, especially those who have solid organ tumors or acute respiratory distress syndrome or require invasive mechanical ventilation (comparing to $10-20 \%$ in HIV PCP) $[2,3,13]$.

Our patient presented with pneumonia (which is the commonest primary manifestation of Pneumocystis jirovecii infection in non-HIV patients with $\mathrm{PCP}[2,3,14]$ and typical diffuse interstitial and intra-alveolar infiltrates on chest X-ray [3]. She had a rare condition: PCP-related spontaneous pneumothorax, pneumomediastinum and subcutaneous emphysema without prior or subsequent use of mechanical ventilation. The higher incidence of spontaneous pneumothorax in AIDS patients with PCP than those without (up to $9 \%$ vs $0 \%$ ) is related to PCP [17]. In previous studies, up to $9 \%$ of hospitalized HIV patients with PCP developed pneumothorax $[19,20]$, but only $2-4 \%$ of non-HIV patients with PCP did [3]. In another cohort of non-HIV patients with PCP who required mechanical ventilation (including $35 \%$ solid organ transplant recipients), 19\% developed pneumothorax [6]. In another study of HIV patients, $20 \%$ of those with PCP developed pneumothorax [19].

The pneumothorax in our patient was likely due to rupture of necrotic lung tissues due to proteases released from activated macrophages and/or alveolar over-distention secondary to bronchiolar inflammation caused by Pneumocystis jirovecii [5, 17]. In previous studies, preceding sub-pleural necrosis, pulmonary cysts or pneumatoceles, and bleb formation with wall thickness thinning occurred in 3-6\% of non-HIV patients with PCP [3, 17]. Neutrophilic lung inflammation may cause pneumothorax [10]. Lower Pneumocystis jirovecii inoculum found in non-HIV patients with PCP may suggest direct invasion or toxicity by the micro-organism as pathogenic mechanism is less substantiated $[3,13]$. Significantly higher neutrophil and lower lymphocyte percentages have been found in bronchoalveolar lavage of non-surviving non-HIV patients with PCP [10]. In a study by Krowka et al., 40-90\% of PBC patients had subclinical fibrosing alveolitis with reduced diffusion capacity of carbon monoxide, which was associated and correlated with PBC clinical and histological severity [21]. Gas exchange abnormality attributed to hypoxaemia and increased breathing efforts may be conducive to pneumothorax. In $\mathrm{PBC}$, it is uncertain but possible that the characteristic $\mathrm{CD} 4$ and activated alveolar macrophages predominating inflammatory infiltration would exaggerate pneumatocele wall thinning, which is conducive to pneumothorax [22].

Pneumomediastinum likely results from air leakage from pneumatoceles and tracks along the bronchovascular 
tissue sheath into the hilum and mediastinum. Mucosal break of the esophagus or tracheobronchial tree with presence of gas-producing micro-organisms may cause pneumomediastinum, with progress involving pericardium [23]. Our patient's conditions were unlikely iatrogenic. Her previous endoscopic retrograde cholangiopancreatography was performed 3 months before her admission. No transbronchial biopsy was taken during fiberoptic bronchoscopy, and no inhaled pentamidine or mechanical ventilation was used [5].

Since CD4 is the main target of HIV, it can be used as a specific marker for PCP prophylaxis threshold in HIV management. In previous studies, the median CD4 level in non-HIV patients at PCP diagnosis was 61 to 329 cells $/ \mu \mathrm{L}$, which was higher than the level in HIV patients $(<50$ cells/ $\mu \mathrm{L})$, and $>35 \%$ of these non-HIV patients had CD $4>300$ cells/ $\mu \mathrm{L}[3,14,24,25]$. On the other hand, HIV patients with current or previous PCP and pneumothorax had CD $4<100$ cells $/ \mu \mathrm{L}$, and $58 \%$ of them had CD $4<50$ cells/ $\mu \mathrm{L}$ [25]. At our center, CD4 check was not routinely performed for non-HIV patients. Our patient's total lymphocyte count of 630 cells $/ \mu \mathrm{L}$ at admission (Table 2) predicted a CD4 level of $<200$ cells/ $\mu \mathrm{L}$ [18]. Clinical parameters as independent predictors of PCP in non-HIV patients include serum albumin $<28 \mathrm{~g} / \mathrm{L}, \mathrm{PaO} 2 / \mathrm{FiO} 2$ ratio $<210$, and $\mathrm{CD} 3<625$ cells $/ \mu \mathrm{L}$ [14]. Our patient had no chronic lung disease, simultaneous bacteremia, or high blood urea nitrogen, which are independent predictors for mortality of non-HIV patients with PCP [10]. Other mortality predictors include $\mathrm{CD} 8<160 \times 10^{6} / \mathrm{L}$ and $\mathrm{PaO} 2 /$ $\mathrm{FiO} 2$ ratio $<160$ [14].

The first-line PCP prophylaxis is TMP-SMX. Alternatives include atovaquone, pyrimethamine, sulfadoxine and dapsone [3]. There are no guidelines on PCP prophylaxis duration for LT recipients. With different centers having different practice, balancing the incidence of PCP and the side effects of medication, the duration varies between 1 and 12 months, or is an indefinite period [4]. Different criteria for routine or targeted post-LT PCP prophylaxis are based on adult incidence rate $\geq 3.5 \%$, anytime total lymphocyte count $<400$ cells/ $\mu \mathrm{L}$, anti-rejection immunosuppressant use, till prednisolone dose $<10 \mathrm{mg} / \mathrm{day}$, or the presence of 2 or more of the following risk factors: pretransplant renal failure, fulminant hepatic failure, retransplantation, intraoperative Roux-loop-hepaticojejunostomy, post-LT intensive care unit stay $>5$ days, renal failure, albumin-creatinine ratio, and total parenteral nutrition $>48 \mathrm{~h}$. Sarwar et al. [4] found that calcineurin inhibitor-based immunosuppressant monotherapy could reduce the risk of PCP after LT without prophylaxis. At our center, immediate post-LT 3-month oral TMP-SMX or monthly inhalation pentamidine is given, depending on the patient's renal function and glucose-6-phosphate dehydrogenase status. The interaction between tacrolimus and mycophenolate mofetil could result in an excessive degree of immunosuppression [26, 27]. The occurrence of PCP was found to be associated with an increased amount of immunosuppression, such as combination of tacrolimus, mycophenolate mofetil, and corticosteroid [28]. Hence, in patient who may require multiple immunosuppressive agents, longer period of PCP prophylaxis should be considered.

The standard PCP treatment is 3-week oral or intravenous TMP-SMX. For TMP-SMX intolerance or non-responsiveness, intravenous pentamidine and combined oral primaquine and intravenous clindamycin are two alternatives [3]. Use of adjuvant corticosteroids in non-HIV patients with PCP with moderate-to-severe severity $\left(\mathrm{PaO}_{2}<70 \mathrm{mmHg}\right.$ at room air) is controversial, although such use has been well established in AIDS patients $[3,10]$. Ongoing assessment for causes of clinical deterioration is crucial for prompt management (and intensive care unit monitoring, if necessary), which is critical in reducing mortality [6].

\section{Conclusion}

PCP in LT recipients has abrupt symptom onset with rapid progression and carries a high mortality rate. Longer period of PCP prophylaxis should be considered in patients who have a higher risk compared to general LT patients. PCP-related pneumothorax rarely occurs in LT recipients. However, vigilance in detecting and excluding rare, potentially fatal but treatable complications is crucial, especially when clinical deterioration has occurred.

\section{Abbreviations}

AIDS: Acquired immune deficiency syndrome; CD4: CD4 T-cells; CMV: Cytomegalovirus; HIV: Human immunodeficiency virus; LT: Liver transplant; PBC: Primary biliary cirrhosis; PCP: Pneumocystis pneumonia; RSV: Respiratory syncytial virus; SMX: Sulphamethoxazole; TMP: Trimethoprim

Funding

This case report received no funding of any kind.

Availability of data and materials

All data are presented in this manuscript and can be accessed through the corresponding author on request.

\section{Authors' contributions}

WHS analyzed and interpreted the patient data regarding the transplant and the infectious disease and was the major contributor in writing the manuscript. KSHC and CML analyzed and interpreted the patient data and oversaw the study. IWSL performed the microbiological examination and contributed to writing the manuscript. KWM, SLS, WCD and JYYF analyzed and interpreted the patient data. All authors read and approved the final manuscript.

\section{Authors' information}

In 2017, our center performed 74 liver transplants in total, including 34 livedonor liver transplants and 40 deceased-donor liver transplants.

\section{Ethics approval and consent to participate}

Ethics approval is not applicable to retrospective review of a past clinical case. All treatments received by the patient were not influenced by this retrospective review. The patient had given her written, informed consent to the use of her data for research. 


\section{Consent for publication}

The patient has given her written consent to publishing her clinical details and/or clinical images.

\section{Competing interests}

The authors declare that they have no competing interests.

\section{Publisher's Note}

Springer Nature remains neutral with regard to jurisdictional claims in published maps and institutional affiliations.

\section{Author details}

'Department of Surgery, The University of Hong Kong, 102 Pok Fu Lam Road, Hong Kong, China. ${ }^{2}$ State Key Laboratory for Liver Research, The University of Hong Kong, 102 Pok Fu Lam Road, Hong Kong, China. ${ }^{3}$ School of Public Health, The University of Hong Kong, 102 Pok Fu Lam Road, Hong Kong, China. ${ }^{4}$ Department of Medicine, The University of Hong Kong, 102 Pok Fu Lam Road, Hong Kong, China.

Received: 29 March 2018 Accepted: 11 January 2019

Published online: 18 January 2019

\section{References}

1. Choi YI, Hwang S, Park GC, Namgoong JM, Jung DH, Song GW, Ha TY, Moon DB, Kim KH, Ahn CS, et al. Clinical outcomes of pneumocystis carini pneumonia in adult liver transplant recipients. Transplant Proc. 2013;45(8): 3057-60.

2. Kostakis ID, Sotiropoulos GC, Kouraklis G. Pneumocystis jirovecii pneumonia in liver transplant recipients: a systematic review. Transplant Proc. 2014;46(9): 3206-8.

3. Roux A, Gonzalez F, Roux M, Mehrad M, Menotti J, Zahar JR, Tadros VX, Azoulay $E$, Brillet PY, Vincent F, et al. Update on pulmonary pneumocystis jirovecii infection in non-HIV patients. Med Mal Infect. 2014;44(5):185-98.

4. Sarwar S, Carey B, Hegarty JE, McCormick PA. Low incidence of pneumocystis jirovecii pneumonia in an unprophylaxed liver transplant cohort. Transpl Infect Dis. 2013;15(5):510-5.

5. Okoh SG, Gopal KV. Pneumothorax in pneumocystis Jirovecii pneumonia: a case report, review of clinical characteristics and management. Am J Case Rep. 2008:9:120-4.

6. Ko Y, Jeong BH, Park HY, Koh WJ, Suh GY, Chung MP, Kwon OJ, Jeon K. Outcomes of pneumocystis pneumonia with respiratory failure in HIVnegative patients. J Crit Care. 2014;29(3):356-61.

7. Boonsarngsuk V, Sirilak S, Kiatboonsri S. Acute respiratory failure due to pneumocystis pneumonia: outcome and prognostic factors. Int J Infect Dis. 2009;13(1):59-66.

8. Stringer JR, Beard CB, Miller RF. Spelling pneumocystis jirovecii. Emerg Infect Dis. 2009;15(3):506.

9. Fagiuoli S, Colli A, Bruno R, Craxi A, Gaeta GB, Grossi P, Mondelli MU, Puoti M, Sagnelli E, Stefani S, et al. Management of infections pre- and post-liver transplantation: report of an AISF consensus conference. J Hepatol. 2014; 60(5):1075-89.

10. Kim SJ, Lee J, Cho YJ, Park YS, Lee CH, Yoon HI, Lee SM, Yim JJ, Lee JH, Yoo $\mathrm{CG}$, et al. Prognostic factors of pneumocystis jirovecii pneumonia in patients without HIV infection. J Inf Secur. 2014;69(1):88-95.

11. Husain $\mathrm{S}$, Singh $\mathrm{N}$. The impact of novel immunosuppressive agents on infections in organ transplant recipients and the interactions of these agents with antimicrobials. Clin Infect Dis. 2002;35(1):53-61.

12. Oz HS, Hughes WT. Novel anti-pneumocystis carinii effects of the immunosuppressant mycophenolate mofetil in contrast to provocative effects of tacrolimus, sirolimus, and dexamethasone. J Infect Dis. 1997; 175(4):901-4.

13. Sokulska M, Kicia M, Wesolowska M, Hendrich AB. Pneumocystis jirovecii-from a commensal to pathogen: clinical and diagnostic review. Parasitol Res. 2015;1 14(10):3577-85.

14. Li Y, Ghannoum M, Deng C, Gao Y, Zhu H, Yu X, Lavergne V. Pneumocystis pneumonia in patients with inflammatory or autoimmune diseases: usefulness of lymphocyte subtyping. Int J Infect Dis. 2017;57:108-15.

15. Musialik J, Petelenz M, Jastrzebski D, Ziora D, Kondera-Anasz Z, Mertas A, Oklek K, Gonciarz Z. Lymphocyte subsets in peripheral blood and bronchoalveolar lavage in patients with primary biliary cirrhosis. Med Sc Monit. 2001;7(Suppl 1):311-5.
16. Webb GJ, Siminovitch KA, Hirschfield GM. The immunogenetics of primary biliary cirrhosis: a comprehensive review. J Autoimmun. 2015;64:42-52.

17. McClellan MD, Miller SB, Parsons PE, Cohn DL. Pneumothorax with pneumocystis carinii pneumonia in AIDS. Incidence and clinical characteristics. Chest. 1991;100(5):1224-8.

18. Poudel SP, Prajapati S, Prajapati BL, Gyawali R, Acharya S, Yadav BK, Uppadhya BP. Utility of Total lymphocyte count as an affordable surrogate for CD4 lymphocyte count in HIV infected Nepali patients. J AIDS Clin Res. 2014;5(3).

19. Ingram RJ, Call S, Andrade A, White C, Wheeler D. Management and outcome of pneumothoraces in patients infected with human immunodeficiency virus. Clin Infect Dis. 1996;23(3):624-7.

20. Kotani T, Katayama S, Miyazaki Y, Fukuda S, Sato Y, Ohsugi K. Risk factors for the mortality of pneumocystis jirovecii pneumonia in non-HIV patients who required mechanical ventilation: a retrospective case series study. Biomed Res Int. 2017;2017:7452604.

21. Krowka MJ, Grambsch PM, Edell ES, Cortese DA, Dickson ER. Primary biliary cirrhosis: relation between hepatic function and pulmonary function in patients who never smoked. Hepatology. 1991;13(6):1095-100.

22. Koksal D, Koksal AS, Gurakar A. Pulmonary manifestations among patients with primary biliary cirrhosis. J Clin Transl Hepatol. 2016;4(3):258-62.

23. Park YK, Jung HC, Kim SY, Kim MY, Jo K, Kim SY, Kang B, Woo G, Choi HJ, Wie SH. Spontaneous Pneumomediastinum, Pneumopericardium, and pneumothorax with respiratory failure in a patient with AIDS and pneumocystis jirovecii pneumonia. Infect Chemother. 2014;46(3):204-8.

24. Enomoto T, Azuma A, Kohno A, Kaneko K, Saito H, Kametaka M, Usuki J, Gemma A, Kudoh S, Nakamura S. Differences in the clinical characteristics of pneumocystis jirovecii pneumonia in immunocompromized patients with and without HIV infection. Respirology. 2010;15(1):126-31.

25. Trachiotis GD, Vricella LA, Alyono D, Aaron BL, Hix WR. Management of AIDS-related pneumothorax. Ann Thorac Surg. 1996;62(6):1608-13.

26. Pou L, Brunet M, Cantarell C, Vidal E, Oppenheimer F, Monforte V, Vilardell J, Roman A, Martorell J, Capdevila L. Mycophenolic acid plasma concentrations: influence of comedication. Ther Drug Monit. 2001;23(1):35-8.

27. Zucker K, Rosen A, Tsaroucha A, de Faria L, Roth D, Ciancio G, Esquenazi V, Burke G, Tzakis A, Miller J. Unexpected augmentation of mycophenolic acid pharmacokinetics in renal transplant patients receiving tacrolimus and mycophenolate mofetil in combination therapy, and analogous in vitro findings. Transpl Immunol. 1997;5(3):225-32.

28. Radisic M, Lattes R, Chapman JF, del Carmen Rial M, Guardia O, Seu F, Gutierrez P, Goldberg J, Casadei DH. Risk factors for pneumocystis carinii pneumonia in kidney transplant recipients: a case-control study. Transpl Infect Dis. 2003;5(2):84-93.

Ready to submit your research? Choose BMC and benefit from:

- fast, convenient online submission

- thorough peer review by experienced researchers in your field

- rapid publication on acceptance

- support for research data, including large and complex data types

- gold Open Access which fosters wider collaboration and increased citations

- maximum visibility for your research: over $100 \mathrm{M}$ website views per year

At $\mathrm{BMC}$, research is always in progress.

Learn more biomedcentral.com/submissions 